\title{
Introduction
}

\author{
Susan R. Madsen
}

Although many scholars do highlight the global progress that has been made in recent decades in terms of the number of women in top positions in government, business, and education (Adler, 2015), Joshi et al. (2015) called this progress "both promising and problematic" (p. 1459). These and other researchers are quick to point out that there are ongoing, persisting challenges with efforts to strengthen women's impact around the world. For example, unequal opportunities and treatment of women (compared to men) remain concerning in nearly all countries, contexts, and sectors (Madsen et al., 2015; Yeganeh and May, 2011). The McKinsey Global Institute's (2015) “The power of parity: How advancing women's equality can add \$12 trillion to global growth" stated that "gender inequality is a pressing global issue with huge ramifications not just for the lives and livelihoods of girls and women, but more generally, for human development, labor markets, productivity, GDP growth, and inequality" (p. ii). My point is that, even with some progress, there is still much more work that needs to be done.

During the past decade, research on gender and leadership has increased dramatically. In addition to my recent co-edited scholarly books - Women and Leadership in Higher Education (Longman and Madsen, 2014), Women as Global Leaders (Ngunjiri and Madsen, 2015), and Women and Leadership around the World (Madsen et al., 2015) thousands of research- and theory-based books and articles have been published on various elements of women and leadership within different sectors, industries, cultures, countries, and contexts. In addition, newspaper, magazine, blog, and other social media articles (for example, stories, editorials, personal perspectives, summaries of research) are released daily within communities, states and provinces, nations, and across the globe. So, the question then becomes: why do we need another book focused on gender and leadership research? Yet, the answer is also clear: although some progress has been made, what we are currently doing is not working. We need more answers. We need more theory. We need more research that addresses questions that have not yet been investigated instead of focusing on studies that confirm what we already know. We need more change interventions based on rigorously tested women and leadership theory and research. We need new findings that get us all thinking outside the box for solutions. We need to shake things up as theorists, scholars, researchers, and practitioners so we can help change the status of women globally.

I do realize this "change the world" mentality irritates some who do not see gender issues as critical or who do not believe that true social change is possible. However, I am boldly asking for nothing less than this: let's change the world together. "Building, Bridging, and Blazing Pathways for Women and Leadership" was the title of the 2013 global women and leadership conference I chaired through the International Leadership Association (ILA, 2013). Today I still believe that we must build (through strategically expanding and deepening theory and research), bridge (through partnerships across academic disciplines, organizations, industries, communities, and others), and blaze 
(by becoming more informed, strengthening our voices, and increasing our courage). Of course this is no small feat, but this is what is needed. A feat is defined as "an act or achievement that shows courage, strength, or skill" (Merriam-Webster Dictionary, n.d.) and "a noteworthy or extraordinary act or achievement, usually displaying boldness, skill, etc." (Dictionary.com, n.d.). Yes, a feat is what is needed to make the vital changes in our world today. I believe that books like this can help. This Handbook, if used as I have intended, can be an important tool for scholars and practitioners to truly build, bridge, and blaze pathways for women and leadership. There are better days ahead.

\section{THE BOOK}

As a senior scholar who studies women and leadership, I used my best thinking to figure out what parts and chapters would be most useful in this Handbook. I based these decisions on current theory and research, and upon what we do and do not know. First, it was clear that it would be important to set the stage for the book by including a few chapters that outlined the current status of women leaders, provided insight into broad areas of work along with calls to action for enhancing women's leadership status worldwide, and explored overarching themes and metaphors that seem to guide current thinking (Chapters 1 through 3). Second, I knew it was also important to highlight some contemporary theoretical lenses that have or should frame our current scholarship. Theories centered specifically on women and leadership are so rare that it is important to understand how frameworks from various disciplines have shaped and can continue to guide our scholarship moving forward (Chapters 4 through 9). Third, there has not been another attempt to deeply interrogate the range of women's individual motivators to lead, so readers will learn a great deal as they consider the latest research on aspirations, ambition, identity, purpose and calling, power, neuroscience, and women's understandings of success and choice (Chapters 10 through 16). Fourth, although there is already a great deal of research on gender-based leadership challenges and barriers, chapters focusing on six key areas are important to the book as a whole (Chapters 17 through 22). And finally, it was important to conclude the book by focusing on the latest research on how to develop women leaders; authors of Chapters 23 through 27 fold in the existing literature discussed throughout the book and summarize current research on how to implement what we currently know about developing women so they can become leaders in companies, communities, and contexts around the world.

\section{Part I: Setting the Stage}

Part I sets the stage for the book as a whole. It includes three chapters, starting with Chapter 1, "The current status of women leaders worldwide," written by Elizabeth Goryunova, Robbyn T. Scribner, and myself, from Utah Valley University. This chapter summarizes the background and available data on the current status of women in regions and countries around the world as it relates to political leadership. The authors then provide current data on the state of women in business leadership, which includes sections on the general situation of women on corporate boards, women as chief executive officers (CEOs) (including entrepreneurs), and women in senior management roles in regions and 
countries. The chapter concludes with a brief discussion of gender parity and provides examples from various groups on when this parity is predicted to occur.

Chapter 2 is written by a wide variety of scholars and practitioners who are part of the Women and Leadership Affinity Group, which is hosted by the International Leadership Association (ILA). The names of these individuals were too numerous to list as authors, but they are included in the Appendix of the chapter. This chapter contains a document that was published independently in 2013 and updated again in 2015, and we are fortunate to have it included in this Handbook to help provide background and context. The Asilomar Declaration and Call to Action on Women and Leadership (Madsen and RosserMims, 2015) is a guide for individual women, women's networks, and other stakeholders and organizations that actively campaign for enhancing women's leadership status worldwide. The document is designed to inspire both its authors and readers to take action in multiple ways to make leadership equality a reality. To this end, the Declaration contains strategic "calls for action" that readers may take to help change the leadership status of women worldwide. These calls for action are preceded by corresponding declarations of the existing realities to help each of us contemplate and integrate new practices into our lives.

Savita Kumra, from Middlesex University in Dubai, wrote Chapter 3 titled "Reflections on glass: second wave feminist theorizing in a third wave feminist age?" In this chapter, she sought to explore the purpose and use of metaphors in the women and leadership literature. This literature abounds with metaphors to describe, examine, and assess the various facilitators and barriers confronting women as they seek to forge their organizational careers, and "glass" has been particularly fruitful in this area. This chapter assesses the combined impact of "glass" metaphors (that is, ceiling, elevator, escalator, and walls) on women as they embark on their career journeys as well as their continued resonance with contemporary feminism. Kumra then discusses whether the " glass" metaphors have served their purpose and, as we progress from second wave liberal feminist ideologies to a third wave age, if it is now time to look beyond the "glass" and seek gender-based organizational analyses that aim to provide some measure of optimism and agency over one's destiny.

\section{Part II: Advancing Women and Leadership Theory}

As Kurt Lewin once articulated, "There is nothing so practical as a good theory" (as cited in Van de Ven, 1989), and Christensen and Raynor (2003) argued that sound theories can help us make predictions and interpret the present to understand what is happening and why. Yet, although there are many generalized leadership frameworks, Jogulu and Wood (2006) argued over a decade ago that the majority of models and theories were developed by men and are based on male-normed assumptions. Ely and Rhode (2010) agreed that, in terms of individual and organizational leadership theories that focus on women, there is clearly a gap in the scholarly literature. They stated: "although theory is rich on how leaders develop, we have little direct empirical evidence about how these processes may differ for women and men and less still about how they unfold in organizations" (p. 395). Ely et al. (2011) argued that "practitioners and educators lack a coherent, theoretically based, and actionable framework for designing and delivering leadership programs for women" (p. 475). And finally, Vetter (2010) supported this notion of a deficit with her 
extensive study of feminist theory scholarship that revealed an "alarming dearth of theoretical analysis of women as leaders" (p. 3).

The point of this background on the need for women and leadership theory is that it is a critical part to include in this book. I must admit that I came up with the idea of having chapters on different approaches or disciplinary perspectives from Nohria and Khurana's (2010) Handbook of Leadership Theory and Practice. They had chapters focusing on leadership theory through the following lenses: organizational behavior, psychology, clinical, sociological, economics, history, and power. I had not found a publication on women and leadership that discussed theory from various viewpoints, so I decided to organize this section similarly, and to include six chapters. I invited six prominent scholars and their colleagues to write through the following lenses: overarching, social psychology, sociology, sociolinguistics, organizational behavior, and human resource development. Of course this is not a comprehensive list of possible perspectives, but at least it is a sampling from which to consider.

The first chapter in this part - Chapter 4, "Creativity in theorizing for women and leadership: a multi-paradigm perspective" - introduces a way to understand the process of theorizing based on women's experiences and ways of knowing. Julia Storberg-Walker (George Washington University) and Kristina Natt och Dag (independent scholar) argue that this new process can serve to advance leadership theories for and by women. They conducted a theoretical analysis of the most highly cited women and leadership theories and offer it as a reflective tool for future theorizing efforts. The key contribution of this chapter is to expand theorizing from a male-dominated practice into a practice centered on women's experience and ways of knowing. To accomplish these goals, the chapter is organized into three main sections. The first section introduces the chapter and describes the importance of theorizing. The second section offers a primer on theorizing, and the third concludes by illuminating how theories from different paradigms have contributed to women and leadership theory.

Chapter 5, "Social psychological approaches to women and leadership theory," written by Crystal L. Hoyt (University of Richmond) and Stefanie Simon (Carleton College), takes a social psychological approach to understanding gender and leadership. In doing so, they explain how both the social context and people's perceptions influence leadership processes involving gender. They frame their chapter by considering the theoretical approaches taken by social psychologists that revolve around two questions: (1) Are there gender differences in leadership style and effectiveness?; and (2) What barriers do women face in the leadership domain? They argue that social psychological research helps to better our understanding of how stereotypes shape expectations people have of female leaders, as well as influence women's own thoughts and behaviors via "stereotype threat" processes. Social psychological approaches to understanding gender and leadership reveal that gender does matter in how people respond to leaders and how leaders approach their roles, regardless of whether it ought to matter.

Next, Christy Glass and Alicia Ingersoll, both from Utah State University, wrote Chapter 6 titled "Sociological approaches to women and leadership theory." They explain that few classical sociological traditions explore the experience of organizational leaders or leadership in a direct way or examine the ways in which gender relations shape access to leadership roles. As a result, there is no clear subfield related to the sociology of leadership. However, classical perspectives inform contemporary theoretical developments 
related to women and leadership in important ways, providing the tools with which contemporary scholars have sought to understand: (1) the factors that contribute to gender bias in leader selection and limit women's access to leadership positions; and (2) the ways in which women experience leadership and the factors that constrain women's ability to lead effectively. This chapter traces the links between classic sociological perspectives on power, status, and inequality to contemporary theories of women and leadership.

Chapter 7, "Sociolinguistic approaches to gender and leadership theory," reviews the range of theories that account for the crucial role of language in women's performance of leadership, as well as the ways women are represented as leaders in the public domain. The author, Judith Baxter (Aston University), states that first, dominance theory proposes that the social nature of language constructs men as more powerful in professional domains and women as less so. Second, difference theory argues that women and men have differently gendered linguistic styles, with men tending to prefer more "transactional" or "goal-orientated" styles of language and women preferring "transformational" or "change-orientated" styles of language. And third, discourse theory proposes that leaders construct their professional identities through the language they choose to use. However, Baxter explains that this is not a free choice, especially for women leaders: gendered discourses such as masculinization or image and sexuality can effectively restrict women's range of identities. This chapter assesses how women leaders are simultaneously enabled and constrained by the language and discourses of leadership.

Chantal Van Esch, Karlygash Assylkhan, and Diana Bilimoria, from Case Western Reserve University, have written a chapter on "Using organizational and management science theories to understand women and leadership" (Chapter 8). In this chapter the authors review several organizational and management science theories that inform women and leadership research. They offer a table of theories, relevant to women and leadership, organized by level of analysis: individual, interpersonal, and organizational. Next, they delve more deeply into select theoretical frameworks at each level to illustrate how women and leadership research may be advanced. At each level, the authors introduce the theoretical perspective, provide an overview of extant research findings specific to women and leadership, explore the implications for advancing knowledge about women and leadership, and offer guidance for future research.

Next, a prominent human resource development scholar, Laura L. Bierema from the University of Georgia, wrote Chapter 9, "No woman left behind: critical leadership development to build gender consciousness and transform organizations." This chapter interrogates prevailing understandings and practices of leadership development using a critical, feminist lens to chart a new path for developing women leaders. Bierema argues that critical feminism offers an unvarnished look at the realities of sexist, patriarchal organizations and analyzes how they perpetuate implicit bias that blocks women from full access to development experiences and advancement opportunities. This chapter embraces Mary Parker Follett's primacy of learning and the process of leadership development to draw on the fields of adult learning and human resource development to offer alternative conceptualizations and pedagogies for leadership development. 


\section{Part III: Individual Motivators to Lead}

This part of the book is close to my heart, as my own research interests through the years have focused on some of these elements. In finding ways to better encourage women toward and to prepare them for leadership, one of the most important and foundational areas of emerging research focuses on understanding women's aspirations and motivations to lead (Madsen, 2008, 2009). In many cases, these driving forces appear to be different for women than for men. As I have done numerous studies through the years on understanding the lifetime development of leadership in high-profile women leaders, I have looked closely for glimpses of how they discovered and strengthened their motivations to lead throughout the years. I have also appreciated the work of my colleagues in honing new areas of discovery such as purpose and calling (Longman et al., 2011; Tunheim and Goldschmidt, 2013). As noted previously, this part of the Handbook delves deeply into the range of women's individual motivators to lead through considering the latest research in aspirations, ambition, identity, purpose and calling, power, neuroscience, and women's understandings of success and choice.

First, a team of authors - Lynne E. Devnew (University of Phoenix), Ann M. Berghout Austin (Utah State University), Marlene Janzen Le Ber (Brescia University College) and Mary Shapiro (Simmons College) - wrote Chapter 10, which is titled "Women's leadership aspirations." The authors recognize that how women and girls perceive leaders and leadership, how they perceive themselves, their self-efficacy in relationship to their perceptions of leadership behaviors, and what they perceive would be the rewards and punishments of being a leader, combine to shape their leadership aspirations. These perceptions are influenced by their work, relationships, and place and thus change throughout each woman's lifetime. The authors argue that raising women's and girls' aspirations is not a simple matter; changes must be made throughout the entire system to enable women and girls to see themselves as leaders, see what leaders do as having value, and see that it is possible to be a leader and still be a successful mother, daughter, partner, and friend.

Second, Chapter 11, "Women's leadership ambition in early careers," was written by two United Kingdom (UK) researchers, Ruth Sealy from the University of Exeter Business School and Charlotte Harman from Cubiks Ltd. They share a new study that looked at the recent deterioration in stated ambition levels of young female professionals, which came to their attention from UK and Irish practitioners in professional service firms who were perceiving a lack of success in the generation of women ahead of them. Sealy and Harman discuss the extant research that has tended to focus either on student perceptions of careers and aspirations or on the older age group struggling to stay in organizational life, and found a gap which they felt should be explored. Therefore, this chapter examines perceptions of women's ambition in early career stages in professional services by reviewing existing literature looking at career motivation and ambition in women, briefly outlining their empirical qualitative study with early career professional women, and then sharing the findings of the study within the context of the literature.

Next, Chapter 12, "Women's leadershipidentity: exploring person and context in theory," was written by three scholars: Wendy Fox-Kirk (Weber State University), Constance Campbell (Georgia Southern University), and Chrys Egan (Salisbury University). They argue that leader identity can positively or negatively impact both leader behavior and others' perceptions of leader behavior. They explain that when the dominant archetype of 
leader behavior is normatively and stereotypically masculine, women are faced with identity struggles and conflicts. In work contexts, dominant leader archetypes can constrain women's ability to build an effective and convincing leader identity. Despite the range of useful theories of identity construction that acknowledges person-context interactions, the focus of most theories and of most leadership development programs remains on the individual, while only minor attention is given to context. In this chapter, these authors present an overview of person-context issues in identity theory and provide a detailed examination of leader identity theories that are particularly useful to women.

Karen A. Longman (Azusa Pacific University) and Debbie Lamm Bray (Northwest University) wrote Chapter 13, "The role of purpose and calling in women's leadership experiences." They argue that over the past 30 years widespread expectations for increasing the number of women in senior-level leadership roles have been based on the highly touted "pipeline theory." Yet scholars have recently been challenging the theory as being male-normed in its assumptions of the values and rewards that motivate leadership aspirations and tenacity for those entering leadership roles. This chapter provides an overview of the literature related to purpose, calling, and leader identity development, making the case that additional, focused attention to these constructs may prove to be a more effective strategy for encouraging women to aspire to - and advance into - leadership roles.

Any discussion of gender and leadership is not complete without an examination of power. "Women, leadership, and power," by Katharina Pick from the Peter F. Drucker and Masatoshi Ito Graduate School of Management at Claremont Graduate University, is Chapter 14 in Part III of this Handbook. Pick argues that women's relationship to power has forever been complex and ambiguous and that there are many power-based explanations for women's leadership outcomes. Research suggests that men and women have differential access to power and differential results from trying to exercise power. She states that a question underlying various related discussions of gender and leadership is whether the relationship between power and leadership is changing, and whether women rising to leadership in increasing numbers may impact this. This chapter briefly reviews basic themes of research on gender and power in leadership in light of the most recent findings about access to power, use of power, and desire for power. Because power, gender, and leadership are not static concepts, Pick considers what conceptual changes are revealed in current research and the impact these may have.

Chapter 15, written by Suzanne J. Peterson and Amy L. Bartels from Arizona State University, focused on "Using neuroscience methods to explore gender differences in leadership." In this chapter the authors discuss current challenges associated with studying gender and leadership from a purely psychological perspective and suggest that neuromethods can complement traditional assessment methods. Peterson and Bartels review evidence derived from studies using brain imaging, endocrinology, and behavioral genetics to advance the discussion of whether gender differences are a biological reality or simply a byproduct of social or perceptual processes. They also emphasize differences related to confidence, risk taking, and leadership style in hopes of contributing to a better understanding of why women continue to face leadership barriers in today's organizations.

Finally, Sarah Leberman and Jane Hurst, from Massey University in New Zealand, wrote Chapter 16, which focuses on "The connection between success, choice, and leadership during women's careers." This chapter reviews the literature associated with women's career conceptualizations of success, notions of choice, and implications for leadership. 
The authors suggest that success is valued differently by women compared with most organizations, leading to a misalignment in expectations. The discourse of choice is identified as a contested space, which has implications on the decisions women make in terms of taking on positional leadership. Leberman and Hurst present a conceptual framework linking success, choice, and leadership and conclude with a series of recommended organizational and individual strategies aimed at supporting and enhancing the careers of women as they move through the twenty-first century.

\section{Part IV: Gender-Based Leadership Challenges and Barriers}

The fourth part of the book focuses on women's challenges and barriers to leading and leadership. Although some elements of gender-based barriers are mentioned in every chapter of this book, having a specific part that summarizes the latest research and findings is critical for a few reasons. First, it is important for future studies to be crafted around questions and hypotheses that are not yet fully understood. In reviewing the literature, we continue to find studies that have explored phenomena already well comprehended. As it is vital that future research focuses on unexplored questions, this part will help set the stage for what is already known. Second, to understand how to develop women leaders, it is important to understand challenges - what is blocking women from moving forward - both internal and external. To be honest, I am sometimes shocked at how many people claim to be women's leadership experts because they can piece together content for a program, a series of lectures, or other initiatives. Some so-called leadership trainers also take the exact material they give in mixed-gender programs and just add "women" at the beginning of the title to offer a women's leadership program. The research is clear that effective women's leadership developers must have deep expertise in all of these areas, including a thorough understanding of the barriers that women face. Interventions then must be based upon this knowledge and carefully crafted into the design of any developmental initiative. The following chapters can provide this information on barriers and challenges to scholars and practitioners alike.

Chapter 17, titled "An overview of gender-based leadership barriers," was authored by Amy B. Diehl (Shippensburg University of Pennsylvania) and Leanne Dzubinski (Biola University). They argue that, despite an abundance of educated, qualified women in the workforce, they continue to be under-represented at the top of institutional leadership hierarchies. Theories of gendered organizations explain that work processes reproduce gendered structures of society in the workplace, and these processes advantage men while forming barriers to women's success. The authors' cross-sector analysis of women leaders in religion and higher education revealed 27 gender-based leadership barriers that operate at the macro, meso, and micro levels of society. They present this framework and then recommend broad strategies that will address barriers across all three levels in order to make them visible, eliminate them, and fully incorporate the potential leadership capacity of both men and women. As you will see, this chapter provides a strong, overarching framework for each of the following chapters.

Michelle Bligh and Ai Ito, while at NEOMA Business School in France, wrote Chapter 18, "Organizational processes and systems that affect women in leadership." They argue that despite the efforts to establish gender equality in organizations, intricate processes and systems hinder women's advancement into top leadership positions. In this chapter, 
they explore many of the organizational level barriers that impact women leaders, including hiring and selection, networking, mentoring, promotion, and negotiation. They have found that understanding each of these processes will help organizations to establish gender-inclusive strategies and gender-neutral policies that will allow women and minorities to navigate through the labyrinth more effectively.

"Individual stresses and strains in the ascent to leadership: gender, work, and family" is the title of Chapter 19, written by Amy E. Smith (University of Massachusetts Boston) and Deneen M. Hatmaker (University of Connecticut). They argue that one explanation for the limited number of women in leadership positions revolves around the tensions between family and career. Even with years of research, attention in the popular press, and the implementation of family-friendly workplace policies, professional women still struggle to navigate the path to having both a meaningful career and a fulfilling family life. In this chapter, the authors discuss the current frames for understanding gendered expectations around work and caregiving. They integrate literature on professional identity and parenthood to advance understanding of the depth and complexity of negotiating work and family. While Hatmaker and Smith focus on the stresses and strains experienced by working women in their aspirations to climb the professional ladder, they also consider the tensions faced by men.

Deborah L. Rhode from Stanford Law School and the Center on the Legal Profession at Stanford University wrote Chapter 20: "Gender stereotypes and unconscious bias." She explained that, although the last quarter-century has witnessed enormous progress for women in leadership positions, the playing field is far from even, and part of the problem is often unconscious gender bias and stereotyping. A major obstacle is the incongruity between qualities associated with women and qualities associated with leaders. Rhode argues that women are subject to a double standard and double bind. She states that what is assertive in a man seems abrasive in a woman, and female employees risk seeming too feminine or not feminine enough. In-group favoritism persists, and women, particularly women of color, are often viewed as less competent and less likely to show leadership potential. Rhode states that addressing these patterns will require both individual and institutional responses. She concludes that organizations need a strong commitment to gender equity, reflected in organizational policies, priorities, and reward structures.

Chapter 21 titled "Theorizing women leaders' negative relations with other women" was written by Sharon Mavin (University of Roehampton), Gina Grandy (University of Regina), and Jannine Williams (University of Bradford). In this chapter, the authors theorize women leaders' negative intra-gender relations with other women and call for a shift in focus from blaming individual women to fuller explanations as to why these social relations emerge. Their theory of women leaders' negative relations with other women explains how these relations take place within gendered contexts where women face gender stereotypes, can do gender well and differently simultaneously, and where homophily, homosociality, women's intra-gender competition, and female misogyny operate as complex, dialectic, dynamic interlocking gendered practices and processes. Their theory illustrates how threats to women's identity constrain and facilitate negative intra-gender behavior between women. It also illustrates how women work to negotiate, resist, and comply with these experiences and how gendered contexts exacerbate differences between women. 
The last chapter in this part of the book discusses "The effect of media on women and leadership" (Chapter 22) written by Carole Elliot (University of Roehampton) and Valerie Stead (Lancaster University). This chapter examines the effect of media on women and leadership by exploring the representation of women's leadership through stereotypes and metaphors. The authors discuss the significance of the media's relationship with women and leadership and provide an overview of literature that draws attention to different ways that women's leadership is represented. They conclude that implications arising from the resilience of stereotypes and metaphors associated with women's leadership are multilayered. They discuss metaphors to draw attention to the challenges women face in achieving leadership positions. Finally, they direct our attention to an uncomfortable environment for women leaders, where gender stereotyping leads to persistent metaphors that pervade the media and popular culture.

\section{Part V: Developing Women Leaders}

All of the chapters thus far have set the stage so that we (for example, scholars, practitioners, colleagues, coaches) can more effectively be engaged in preparing women for leadership and in supporting and strengthening those who are currently leading. By clearly understanding the latest scholarship related to the current status and situation of women (Part I), the current theoretical frameworks through various lenses (Part II), the individual motivators to lead (Part III), and the gender-based leadership challenges and barriers (Part IV), I believe that we can be more prepared to develop girls and women to become leaders (Part V). The final five chapters are focused on this goal: to develop women leaders.

To begin this final part of the book, Chapter 23, titled "Advancing women through developmental relationships," was written by Wendy M. Murphy and Kerry Roberts Gibson from Babson College, and Kathy E. Kram from Boston University. They explain that over the past 30 years, research has shown that developmental relationships facilitate career success, particularly for leaders. In addition, multiple developers (for example, mentors, sponsors, or peers), rather than just one, enhance individuals' growth and advancement. The authors state that these developmental networks are essential to sustained learning and leadership growth. They draw on the literatures on leadership, identity, and positive relationships at work to provide a foundation for understanding how to advance women through developmental relationships. They argue that five specific types of developmental relationships are critical for growing women leaders (that is, mentors, sponsors, peers, executive coaches, and learning partners), and that these developers provide a range of supportive functions that both challenge and enable women to learn and thrive as they advance. The authors conclude by discussing strategies for individual women crafting these developmental relationships, and how organizations can create and sustain a climate that fosters these connections.

Chapter 24, "Gender differences in developmental experiences," was written by Cathleen Clerkin (Center for Creative Leadership) and Meena S. Wilson (Ashoka University). These authors argue that advancement to top positions in any organization requires learning from a variety of experiences. Since both leadership development and career advancement are contingent on accessing the right experiences, in the right context, at the right career juncture, an analysis of the most salient similarities and differences 
between women's and men's experiences is an important entry-point for expanding our understanding of gender and leadership. Clerkin and Wilson found gendered variation in access to and use of the typical developmental experiences needed to become effective toplevel leaders. They explored these gender differences in regard to quantity, quality, and specific type of experiences provided to women and men. They put forward two propositions: (1) women miss out on several critical job experiences that would prepare them for senior management roles; and (2) the life experiences and capabilities that prepare women to be outstanding senior leaders do not carry gravitas in the circles in which organizational selection and promotion decisions are made. They conclude by mapping the way forward and outlining implications for future research and practice.

Of course a section on developing women leaders would not be complete without a discussion of "Women-only leadership programs: a deeper look," which is the title of Chapter 25 of this Handbook. Mary Ellen Kassotakis (Oracle Women's Leadership Initiative) discusses a literature review she conducted for a 15-year time period (2001 to early 2016) to explore the leadership skills needed by women, particularly in senior leadership positions in the Western world, to fill the pipeline of senior positions. In addition to development experiences in mixed gender groups, she also found that there is a distinct place for women-only programs. The results of the literature review indicate that a focus on women-only leadership development programs - whether offered by universities, corporations, or large, global consulting firms - can be a key lever in growing core talent in the quest to maximize the talent potential and profitability of organizational success.

Ronald J. Burke (York University) wrote Chapter 26, which is titled "Supporting women's career development." The purpose of this chapter was to present a variety of issues surrounding the support of women in the workplace through career development. Burke discusses women's career models and types, values of managerial women at work, initiatives supporting women's career development, and finally, implications and conclusions. Within these chapter sections, a variety of career aspects are discussed. For example, the author argues that men's and women's careers are different, with women's having more complex patterns and histories. He believes that it is also important to determine what women value at work, in order to discuss career development initiatives that organizations should consider implementing. Implications for practice are also provided with some thoughts on moving forward.

The book then concludes with a chapter that looks at "Future strategies for developing women as leaders" (Chapter 27). Faith Wambura Ngunjiri (Concordia College) and Rita A. Gardiner (University of Western Ontario) argue that as women continue to be under-represented in leadership positions, it is imperative to think and act creatively to enhance the pipeline of women available and able to take on increasing responsibilities in their organizations. In this chapter, the authors begin by engaging with what the previous four chapters in this part of the Handbook discussed regarding developing women leaders, then provide a succinct critical review of recent literature on women's leadership development strategies, before proposing the need for using an intersectional framework in leadership development programming for women. The authors recognize the need to engage critically with the positionality of women at the nexus of their various identities and roles, the place of identity in leadership development for women, and how women's leadership development efforts can potentially help women to overcome the barriers to their ascent to positions of authority. 


\section{CONCLUSION}

I hope readers will take the time to read this book in full. Each part has valuable chapters that can provide the latest in scholarship - both theory and practice. I would encourage you to read with a reflective lens, so that you can discover findings that relate to your own as well as others' lives. I believe that many of us who do this work feel "called" to do so either by a higher power or just by feeling that we were "made" to do it: it feels right and this is where our interests and hearts lie. Frederick Buechner (1973) once asserted that true vocation joins self and service in "the place where your deep gladness meets the world's deep need" (p. 119). This is how I feel in my own work. I have found this place of gladness, and I have appreciated working alongside a wonderful set of authors who have contributed to this book - and many of you as well.

For me, this journey of strengthening each other - in so many different ways - has been transformational in my own life. As Parker Palmer (2000) once said:

Our deepest calling is to grow into our own authentic selfhood, whether or not it conforms to some image of who we ought to be. As we do so, we will not only find the joy that every human being seeks - we will also find our path of authentic service in the world. (p. 16)

Although there are so many needs in the world related to women, I believe that we can and are truly doing our part as women and men engaged in this work. If you are new to the field of women's leadership, I encourage you to join this movement - as theorists, researchers, scholars, practitioners, and leaders - to advocate for changes that need to be made. It is our turn to stand up, step forward, and make a difference in the world. It is our turn to build, bridge, and blaze new pathways for women and leadership.

\section{REFERENCES}

Adler, N. (2015). Women leaders: Shaping history in the 21st century. In F.W. Ngunjiri and S.R. Madsen (Eds), Women as Global Leaders (pp. 21-50). Charlotte, NC: Information Age Publishing.

Buechner, F. (1973). Wishful Thinking: A Seeker's ABC. New York, NY: Harper \& Row.

Christensen, C.M., and Raynor, M.E. (2003). Why hard-nosed executives should care about management theory. Harvard Business Review, 81(9), 66-75.

Dictionary.com. (n.d.). Feat. Retrieved from http://www.dictionary.com/browse/feat.

Ely, R.J., Ibarra, H., and Kolb, D.M. (2011). Taking gender into account: Theory and design for women's leadership development programs. Academy of Management Learning and Education, 10(3), 474- 493.

Ely, R.J., and Rhode, D.L. (2010). Women and leadership: Defining the challenges. In N. Nohria and R. Khurana (Eds), Handbook of Leadership Theory and Practice (pp. 377-410). Cambridge, MA: Harvard Business Press.

International Leadership Association (ILO) (2013). The International Leadership Association Women and Leadership Affinity Group inaugural conference program. Retrieved from http://www.ila-net.org/WLC/ WLC13/wl2013program.pdf.

Jogulu, U.D., and Wood, G.J. (2006). The role of leadership theory in raising the profile of women in management. Equal Opportunities International, 25(4), 236-250.

Joshi, A., Neely, B., Emrich, C., Griffiths, D., and George, G. (2015). Gender research in AMJ: An overview of five decades of empirical research and calls to action. Academy of Management Journal, 58(5), 1459-1475.

Longman, K., Dahlvig, J., Wikkerink, R., Cunningham, D., and O'Connor, C.M. (2011). Conceptualization of calling: A grounded theory exploration of CCCU women leaders. Christian Higher Education, 10(3-4), 254-275. doi 10.1080/15363759.2011.576213.

Longman, K.A., and Madsen, S.R. (Eds). (2014). Women and Leadership in Higher Education. Charlotte, NC: Information Age Publishing. 
Madsen, S.R. (2008). On Becoming a Women Leader: Learning from the Experiences of University Presidents. San Francisco, CA: Jossey-Bass.

Madsen, S.R. (2009). Developing Leadership: Learning from the Experiences of Women Governors. Lanham, MD: University Press of America.

Madsen, S.R., Ngunjiri, F.W., Longman, K.A., and Cherrey, C. (Eds). (2015). Women and Leadership around the World. Charlotte, NC: Information Age Publishing.

Madsen, S.R., and Rosser-Mims, D. (Compilers). (2015). Asilomar Declaration and Call to Action on Women and Leadership. Women and Leadership Affinity Group, International Leadership Association. Retrieved from http://www.ila-net.org/Communities/AG/Asilomar_Declaration2015.pdf.

McKinsey Global Institute. (2015). The power of parity: How advancing women's equality can add $\$ 12$ trillion to global growth. September. Retrieved from http://www.mckinsey.com/global-themes/employment-and-growth/ how-advancing-womens-equality-can-add-12-trillion-to-global-growth.

Merriam-Webster Dictionary. (n.d.). Feat. Retrieved from http://www.merriam-webster.com/dictionary/feat.

Ngunjiri, F.W., and Madsen, S.R. (Eds). (2015). Women as Global Leaders. Charlotte, NC: Information Age Publishing.

Nohria, N., and Khurana, R. (2010). Handbook of Leadership Theory and Practice. Cambridge, MA: Harvard Business Press.

Palmer, P.J. (2000). Let Your Life Speak: Listening for the Voice of Vocation. San Francisco, CA: Jossey-Bass.

Tunheim, K.A., and Goldschmidt, A.N. (2013). Exploring the role of calling in the professional journeys of college presidents. Journal of Leadership, Accountability and Ethics, 10(4), 30-40.

Van de Ven, A.H. (1989). Nothing is quite so practical as a good theory. Academy of Management Review, 14(4), 486-489.

Vetter, L.P. (2010). Overview: Feminist theories of leadership. In K. O'Connor (Ed.), Gender and Women's Leadership: A Reference Handbook (pp. 3-10). Thousand Oaks, CA: Sage.

Yeganeh, H., and May, D. (2011). Cultural values and gender gap: A cross-national analysis. Gender in Management: An International Journal, 26(2), 106-121. 
Susan R. Madsen - 9781785363863 Downloaded from PubFactory at 04/26/2023 $09: 48: 37 \mathrm{AM}$ via free access 